Path. Microbiol. 1961;24:I-XII

\title{
Contents, Vol. 24, 1961
}

OfiBzielles Organ der Treien Vereinigung Schweizer Pathologen/Schweiz. Mikrobiologischen Gesellschaft Organe officiel de ГAssociation libre des Pathologistes Suisses/la Société Suisse de Microbiologie

H. BERGSTRAND, Stockholm

R. BIELING, Wien

H. CHIARI, Wien

M. DJURISIC, Beograd

J. FIRKET, Liège

C. HALLAUER, Bern

E. LETTERER, Tubingen

E. G. NAUCK, Hamburg

COLLABORATORES

J. L. NICOD, Lausanne A. L. OLITZKI, Jerusalem R. H. REGAMEY, Geneve F. C. ROULET, Basel E. RUTISHAUSER, Geneve M. et R. SILBERBERG,

Saint Louis, Mo. H. SMETANA, Washington

J. TOMCSIK, Basel R. TULASNE, Strasbourg E. UEHLINGER, Zurich H. ÜNGAR, Jerusalem B.WALTHARD, Bern M.WELSCH, Liège A.WERTHEMANN, Basel K. C. WINKLER, Utrecht

REDACTORES A. v.ALBERTINI, Zurich A. GRUMBACH, Zurich H. MOO SER, Zurich J. R. RÜTTNER, Zurich

Vol. 24

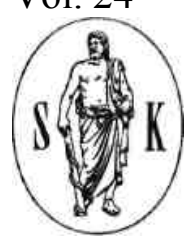

1961

\section{BASEL (Schweiz) S. KARGER NEW YORK}

Alle Rechte, insbesondere das de $\Gamma$ Übersetzung in fremde Sprachen, vorbehalten.

Ohne ausdrückliche Genehmigung des Verlages ist es auch nicht gestattet, dieses Buch oder

Teile daraus auf photomechaníschem Wege (Photokopie, Mikrokopie) zu vervielfältigen.

(C)

Copyright 1961 by S. Karger A.G., Basel Printed in Switzerland by Buchdruckerei Friedrich Reinhardt A.G., Basel Cliches: Steiner \& Cie. A.G., Basel, und Aberegg-Steiner \& Cie. A.G., Bern

Index

Agüero, 0.: Anderson, M.:

Angevine, C. D.: Annitto, J. E.:

Vide Gavallér, B. v. Vide Dixon, H. G. Vide Lalich, J. J. Vide Chesley, L. C. 
Arber, W. und Lataste-Dorolle, C.:

Erweiterung des Wirtsbereiches des Bakteriophagen $\lambda$ auf Escherichia

coliB 1012

Babudieri, B.: The Slide-Microagglutination Test (S.M.A.T.) in the Field of Rickettsial and Viral Serology. Its Advantages and Limitations.... Suppl. 11

Baird, D.: $\quad$ General Summary 557

Bednár, B.: Vide Raska, K.

Bertschinger, H. U.:

Vide Scholer, H. J.

Beumer, J. et Dirkx, J.:

Antigènes somatiques des shigellæ et recepteurs des bacteriophages 999

Bianchi, L.: Experimentelle Untersuchungen über Gefäßveränderungen der

Röntgenniere 270

Bigler, F.: $\quad$ Vide Thölen, $H$.

Blanc, G.: Comportement de Rickettsia burneti Derrick chez la tique Hyalomma ægyptium (LIN) et la tortue terrestre Testudo græca LIN . . . Suppl. 21

Böhni, E.: Vide Fust, B.

Borowski, J.: Production of Penicillinase by Micrococci. Correlation between their Ability to Produce Penicillinase and the Results of some Laboratory

Tests for Penicillin Sensitivity

Bras, G.: $\quad$ Vide Watler, D. C.

Brodhage, H.: Über die Sensibilität von Salmonellen auf Madribon 363

Brooks, S. E. H.: Vide Watler, D. C.

Brunschwiler, F.: Vide Kästli, P.

Brzezinski, A.; Serb, D. M. and Koren, Z.:

Comparative Studies on Pre-Eclampsia and Eclampsia in Israel Im

migrant Populations 452

Bürki, F.: Agglutination und Komplementbindungsreaktion an Goldhamstern nach Infektion mit Leptospira pomona $\quad 977$

Burdzy, K.: Vide Parnas, J.

Burgdorfer, W.: Evaluation of the Fluorescent Antibody Technique for the Detection of Rocky Mountain Spotted Fever Rickettsiae in Various Tissues . Suppl. 27

Burgisser, 1·L: Saccharomycopsisguttulatusest-ilréellementpathogènepourlelapin? 357

Burgisser, H.; Fankhauser, R.; Kaplan, W.; Klingler, K. und Scholer, H. J.:

Mykose bei einem Dachs in der Schweiz: Histologisch Histoplasmose 794 Burgisser, H.: Vide

Nicod, J. L. Cabasso, V. J.: Vide Cox, H. R.

Caesar, R.: Elektronenmikroskopische Untersuchungen an menschlichem Amy

loid bei verschiedenen Grundkrankheiten 387

Capponi, M.: Vide Giroud, P.

Castañeda, M. R.: On the Evaluation of Diagnostic Tests for Brucellosis .... Suppl. 40

Chesley, L. C.: Renal Function in Relation to Salt and Water Regulation in Normal

and Toxemic Pregnancy 631

Chesley, L. C; Cosgrove, R. A. and Annitto, J. E.:

Pregnancy in the Sisters and Daughters of Eclamptic Women . . 662

Chodat, F. et Gouda, S.:

Contribution à $\Gamma$ étude du pigment de Pseudomonas fluorescens Mig. 840 
Ciplea, A. G.: Vide CiucÃ, M.

Ciuc Ã, M. et Ciplea, A. G.:

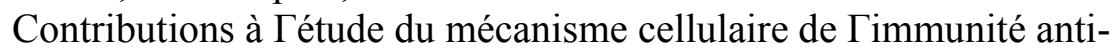

bactérienne Suppl. 45

Claireaux, A. E.: Perinatal Mortality in Toxaemia of Pregnancy

607

Cochrane, A. L.: Vide Miall, W. E.

Corkill, T. F.: Experience of Toxaemia Control in Australia and New Zealand . 428

Cosgrove, R. A.: Vide Chesley, L. C.

Cottier, H.; Keller, H. und Roos, B.:

Generalisierte Hyperostosis interna und Osteosarkome bei ganzbe-

strahlten Mäusen mit hormonal aktiven Ovarialtumoren 276

Cottier, H.: Vide Roos, B.

Cox, H. R.; Cabasso, V. J.; Embil, J.; Markham, F. S.; Moses, M. J.; Moyer, A. W.; Roca-

Garcia, M. and Ruegsegger, J. M.: Immunization against Poliomyelitis with a Trivalent Oral

Vaccine Suppl. 61

Daamen, C. B. F.: The Change in the Frequency of Eclampsia before and after World

War II (1939-1945) 513

Da Silva Lacaz, C.:

Vide Fava Netto, C.

Davey, D. A. and O'Sullivan, W. J.:

Sodium Metabolism in Normal Pregnancy and Pre-Eclampsia . . . 642

Dawkins, M. J. R. and Wigglesworth, J. S.:

Serum Isocitric Dehydrogenase in Normal Pregnancy and Pre-Ec-

lamptic Toxaemia 655

De Brito, T.: Vide Fava Netto, C.

Derrick, E. H.: The Changing Pattern of Q Fever in Queensland 73

Dirkx, J.: $\quad$ Vide Beumer, J.

Dixon, H. G. and Anderson, M.:

Survey of Pre-Eclampsia and Eclampsia 1958-59 498

Dixon, H. G. and Robertson, W. B.:

Vascular Changes in the Placental Bed 622

Doll, R. and Hanington, E.:

International Survey of Eclampsia and Pre-Eclampsia, 1958-59:

Epidemiological Aspects 531

Dominguez, A.: Vide Gavalléh, B. v.

Dbiscoll, J. M.: Vide Murray, E. S.

Dumas, N.: Vide Giroud, P.

Embil, J.: $\quad$ Vide Cox, H. R.

Emerson, H.: Vide Price, W. H.

Fankhauser, R.: Vide Burgisseh, H.

Fava Netto, C.; De Brito, T. and Da Silva Lacaz, C.:

Experimental South American Blastomycosis of the Guinea Pig . 192

Fey, H. und Margadant, A.:

Hypogammaglobulinämie bei der Colisepsis des Kalbes $\quad 970$

Flamm, H. und Wiedermann, G.: 
Spezifische Immunologische Toleranz gegen Bakterielle Antigene bei erwachsenen Versuchstieren 1099

Fouhnier, R.: Vide Varela, G.

Fuller, H. S. Vide Vinson, J. W.

Fust, B. and Böhni, E.:

A Rapid Disk Method for Determining the Susceptibility of Bacteria

to Madribon, other Sulfonamides and Antibiotics. (With Plate II) . 378

Gaon, J.: Die Rolle der Brill-Zinsser'schen Krankheit in der Epidemiologie des

Fleckfiebers in Bosnien und der Herzegowina (Jugoslawien) . . Suppl. 80

Gaon, J.: Vide Murray, E. S.

Gardiol, D.: Critères histologiques du diagnostic étiologique des cirrhoses .... 249

Gavallér, B. v. and Agüero, 0.:

Toxemias of Pregnancy in Venezuela 488

Gavallér, B. v. und Dominguez, A.:

Apoplektische Blutungen in der Schwangerschaftstoxikose .... 595 Geigy, R. und Sarasin, G.:

Einflüsse verschiedener Medien auf Borrelia duttoniSuppl. 93

Gillissen, G. und Wagner, H. J.:

Die quantitative Beeinflussung der Schwefelwasserstoffbildung von

Proteusbakterien durch subbakteriostatische Antibiotikakonzentra-

tionen 1107

Giroud, P.; Capponi, M. et Dumas, N.:

Mise en evidence d'un agent du groupe des rickettsies sur Dermacentor

marginatus, prélevé sur bovin dans le Centre de la France. Essai de

modification du type Suppl. 104

Gloor, F.; Löffler, A. und Scholer, H. J.:

Mucormycosen 1043

Goodall, H. B.: Haemóglobinuria in Eclampsia and its Relationship to Hepatic Dam age $\quad 602$

Goodall, H. B.: Megaloblastic Anaemia of Pregnancy and the Puerperium 682

Goreczky, L.: On the Localisation of Immune Bodies 13

Gouda, S.: Vide Chodat, $\Gamma$.

Govan, A. D. T.: The Pathogenesis of Eclamptic Lesions 561

Grauwiler, J.: Vide Jasinski, B.

Gross, Th., J.: Über den histologischen Auf bau der Herzklappen des Meerschweinchens 397

Gubler, H. U.: Der Nachweis von Masernvirus im Explantat durch Haemagglutination 984

Haller, J.: Vide Hosemann, H.

Hanington, E.: The Relationship of the ABO Blood Groups to Pregnancy, and Tox

aemia 687

Hanington, E.: Vide Doll, R.

Hartroft, W. S.: Vide Suzuki, M.

Hedinger, Chr. und Plattner, D.:

Dysgenetische, sogenannte hypoplastische Zonen in retinierten und

beidseits normal deszendierten Hoden

227

Heller, H.; Sohar, E. and Pras, M.: 
Ethnic Distribution and Amyloidosis in Familial Mediterranean Fever

(FMF) 718

Hellmich, H.: Vide Hosemann, $\mathrm{H}$.

Henschen, F.: Cribra Cranii, a Skull Condition Said to be of Racial or Geographical

Nature 724

Hosemann, H.; Hellmich, H. and Haller, J.:

Follow-up Studies on Posttoxaemic Maternal Residual Changes . . 667

Hueper, W. C.: Carcinogenic Studies on Water-Insoluble Polymers 77

Ishikawa, E.: The Kidney in the Toxemias of Pregnancy 576

Jadin, J.: $\quad$ Aspects actuels des rickettsioses au Congo et au Ruanda-Urundi . Suppl. 112

Jakobsson, P. H. J.:

Communication on Eclampsia and Pre-Eclampsia in Pregnancy in Ice

land for the Period of 1st July 1958 to 30th June 1959

Jasinski, B. und Grauwiler, J.:

Die Wirkung von Knorpel- und Knochenmarkextrakt auf das durch

Cortison gehemmte Granulationsgewebe nach subkutaner Fremd-

körper-Implantation bei der Ratte 148

Jenny, L.: Better Color Reproduction in Photographing Sensitivity of Bacteria

in the Disk Plate Methode Using Blood as Indicator by a Varied Color

Process 384

Kästli, P. und Brunschwiler, F.:

Wie lange und in welchen Mengen werden Antibiotika bei der intra-mammären Behandlung der

Kuh mit der Milch ausgeschieden? . . 774

Kaplan, W.: Vide Burgisser, H.

Kaudewitz, F.: Zur Genetik antigener Strukturen von Enterobacteriaceen 910

Kauffmann, F.: Zur Serologie der somatischen Enterobacteriaceae-Antigene .... 860

Keller, H.: $\quad$ Vide Cottier, H.

Keller, R.: $\quad$ Zum Mechanismus der Mastzelldisruption 932

Klingler, K.: Vide Burgisser, $\mathrm{H}$.

Klopper, A.: Oestriol Excretion in Pre-Eclampsia 652

Knüsel, F.: Durch Vitamin B12, Nukleinsäuren und deren Bausteine bedingte

Wachstumsförderung und Veränderung der Form der Bakterienzelle

bei Lactobazillen $\quad 848$

Konsanszky, A.: Untersuchungen über den Stoffwechsel der Hefe. V. Die Wirkung ver-

schiedener aliphatischer SH- und aliphatischer S-S-Verbindungen auf

die Aktivität der Hefe-Dehydrogenasen

1

Konsanszky, A.: Untersuchungen über die Wirkung verschiedener aliphatischer SH-

Verbindungen auf die Dehydrogenasen der Rattenleber 157

Koren, Z.: $\quad$ Vide Brzezinski, A.

Kurmann, J.: Nachweis und Vorkommen von Cl. perfringens in Milch 733

Kutzner, H. J.: Effect of Various Factors on the Efficiency of Plating and Plaque

Morphology of some Streptomyces Phages 30

Kutzner, H. J.: Specificity of Actinophages within a Selected Group of Streptomyces 170

Lalich, J. J.; Wirka Jr., H. W. and Angevine, C. D.:

Influence of /?-Aminopropionitrile Feeding on Collagen Synthesis in

Rat Aortas $\quad 140$ 
Lannigan, R.: Vide Pirani, C. L.

Lataste-Dorolle, C.: Vide Arber, W.

Laufer, A. and Plaschkes, J.:

Primary Leiomyosarcoma of the Inferior Vena Cava $\quad 72$

Laufer, A.: Vide Ungar, $\mathrm{H}$.

Lawson, J. B.: Pre-Eclampsia and Eclampsia in Nigeria 478

Likar, M.: $\quad$ Use of Human Embryonic and Baby Kidney Cultures in the Study

of Enteroviruses $\quad 415$

Likar, M.: Vide Nestorova, L.

Litschel, E.: Über menschliche Normalagglutinine gegen Schaf- und Rinderery-

throcyten 954

Löffler, A.: Vide Gloor, F.

Löffler, H.: $\quad$ Der inkomplette Entwicklungszyklus von Influenza-Virus in HeLa-

Zellen. Fluoreszenz-mikroskopische Untersuchungen 988

Lüderitz, O.: Vide Westphal, 0.

Lutz, A.: Recherche sur Taction antibactérienne et cicatrisante d'une poly-

oxyméthylénurée. I. Données expérimentales sur Taction antibacté

rienne «in vitro» et «in vivo » 285

Lutz, A. et Witz-Berger, M. A.:

Recherche sur Гaction antibactérienne et cicatrisante d'une polyoxy-

méthylénurée. II. Données expérimentales sur Гaction cicatrisante.

(Avec Planche I) 293

McClure Browne, J. C.:

Survey of Eclampsia - Clinical Aspects 542

MacGillivkay, I.: $\quad$ Pre-Eclampsia in Great Britain and Ireland 507

MacGillivkay, I.: $\quad$ Salt and Water Balance in Normal and Toxaemic Pregnancy ...

Magara, M.: A Study on the Intrinsic Factors of the Toxaemia of Pregnancy . . 670

Magara, M.: Vide Takaki, F.

Magee, T. P.: Socio-Economic Aspects of Pre-Eclampsia and Eclampsia in the

Obstetric Unit of the Colonial Hospital, Port of Spain, Trinidad, West

Indies 504

Mahnke, P.-F.; Zschoch, H. und Sichert, H.:

Pilzbefunde im Tracheobronchialbaum des Menschen. Häufigkeit,

Arten und pathogenetische Bedeutung $\quad 327$

Mahran, M.: Water and Electrolyte Metabolism in Pregnant Women. A Compara

tive Study of Normal and Toxaemic Women 647

Margadant, A.: Vide Fey, H.

Markham, F. S.: Vide Cox, H. R.

Mastboom, J. L.: Incidence of Eclampsia and Maternal Mortality from Eclampsia in the

Netherlands during the Period from 1920 to 1960474

Meier, R. und Schuler, W.:

Wirkung von Metallionen auf den Gas-Stoffwechsel von Bäckerhefe. $\quad 52$

Meisel, H.; Trembowler, P. und Pogorzelska, B.:

Über Perfringens-Clostridien als Bestandteil der normalen, fäkalen

Bakterienflora beim Menschen 307

Miall, W. E. and Cochrane, A. L.: 
The Distribution of Arterial Pressure in Wales and Jamaica

690

Milgrom, F.: Vide Müller-Ruchholtz, W.

Moses, M. J.: Vide Cox, H. R.

Moyer, A. W.: Vide Cox, H. R.

Mühlethaler, J. P.:

Ausschnitte aus der Pathologie des Neugeborenen. Herpes simplex

generalisatus und Aplasie der Vena pulmonaris communis 255

Müller-Ruchholtz, W. and Milgrom, F.:

Serological Studies on Thoracic Duct Lymph 317

Murray, E. S·; Gaon, J.; Driscoll, J. M. and Snyder, J. C.:

Determination of Serological Immunity to Epidemic Typhus by

Response to Vaccine Suppl. 122

Nestorova, L. and Likar, M.:

Serological Evidence for Group A Arthropod-Borne Virus Antibodies

in Some Human and Animal Sera 1129

Nettles, J. B.: Vide Pirani, C. L.

Nicod, J. L. et Burgisser, H.:

Lymphadénopathie gigantofolliculaire (Brill-Symmers) chez un lièvre 409

O’Neal, R. M.: Vide Suzuki, M.

0'Sullivan, W. J.: Vide Davey, D. A.

Parnas, J. and Burdzy, K.:

Antigenic Structure of some Parvobacteriaceae 341

Samochowiec, E.: Vide Swierczyiñska, Z.

Sarasin, G.: Vide Geigy, R.

Scheidegger, S.: Omithose 239

Scherrer, R.: Über den Mechanismus der Gramfärbung. Sitz der Gramreaktion bei

Bacillus M 756

Scherrer-Gervai, M.:

Vide Tomcsik, J.

Schiff, W.: Über einen in vivo wirksamen antibämolytischen SchutzstofF («Diph-

tbin») aus Corynebakterien 299

Schneider, P. A.: Vide Scholer, H. J.

Scholer, H. J.; Schneider, P. A. und Bertschinger, H. U.:

Nacbweis von Cryptococcus neoformans und anderen Hefen aus

Milch von Kühen mit Mastitis

803

Scholer, H. J.: Vide Burgisser, H.

Scholer, H. J.: Vide Gloor, F.

Scholer, H. J.: Vide Richle, R.

Schuler, W.: Vide Meier, R.

Serr, D. M.: Vide Brzezinski, A.

Sharon, N.: The Employment of a Streptomycin Dependent Strain of Pasteurella

pestis as a First Step in a Two-Step Vaccination Procedure .... 1091

Shelley, H. J.: Vide Parry, H. B.

Sichert, H.: Vide Mahnke, P.-F.

Siebenmann, R. E.: Pseudohermaphroditismus masculinus mit Gonadoblastom - eine besondere Intersexform 233 
Siegel, B. V. and Smith, M. E.:

Tissue Culture Studies on the Lymphomas with Particular Reference

to Hodgkin's Disease 1072

Smith, M. E.: Vide Siegel, B. V.

Snydeh, J. C.: Vide Murray, E. S.

Sohar, E.: $\quad$ Vide Heller, H.

Sparrow, H.: Sur une souche de Rickettsia quintana isolée en Tunisie. . . Suppl. 140

Staub, A. M.: Constitution chimique de quelques sites presents à la surface des

enterobacteriaceae responsables de leur spécificité vis-à-vis des anti-

corps et des bactériophages 890

Staub, H.: $\quad$ Vide Thölen, H.

Steck, F.: Untersuchungen über die Gammaglobulinresorption des neugeborenen

Kalbes mit Hilfe von Immunpräzipitationsmethoden 963

Stein, P.: Vide Pirani, C. L.

Stofer, A. R.: Lungenschädigungen durch feste und flüssige organische Substanzen 107

Studer, A.: $\quad$ Einfluß von Pharmaka auf die Histochemie des Nebennierenmarkes

der Ratte 221

Surján, L. and Surján, M.:

Chemical Investigations of the Capsular Substance of Klebsiella

ozaenae and $\mathrm{Kl}$. scleromatis

370

Suzuki, M.; O’Neal, R. M. and Hartroft, W. S.:

Esterification of Cholesterol Related to Hepatic State in Rats with Hypercholesterolemia: Effects of Saturated Fat (Butter) Versus Unsaturated Fat (Corn Oil) 1080

Swierczynska, Z. and Samochowiec, E.:

Serological Method of Detecting Choriongonadotropin as a Test for

Pregnancy 67

Takaki, F.; Magara, M. and Yuasa, S.:

"Toxemias of Pregnancy" in Japan 459

Thölen, H.; Bigler, F. und Staub, H.:

Zur Pathogenese des Urämiesyndroms. I. Mitteilung: Der Gehalt

von Acetoin und 2,3-Butylenglykol im Blut urämischer Patienten . 262

Tomcsik, J. und Scherrer-Gervai, M.:

Einwirkung der Neutralsalze auf die Erythrocytenmembranen . . 945

Trembowler, P.: Vide Meisel, H.

Turay, P. und Pettkó, E. F.:

Die Hemmung des Pasteur'schen Effektes mit einer SH-haltigen Ver-

bindung in vivo

17

Turian, G.: Cycle glyoxylique, transaminase alanine-glyoxylate et díférenciation sexuelle chez Allomyces et Neurospora

Ungar, H. and Laufer, A.:

Necropsy Survey of Atherosclerosis in the Jewish Population of Israel.

Preliminary Report 711

Vaixadares, Y.: Studies on Cancerous Pathogenesis. Cancer in an Eight Day Mouse

Embryo Promoted by Cancerous Desoxyribonucleic Acid 1114 
Varela, G. y Fournier, R.:

Presencia de Rickettsia quintana en piojos Pediculus humanus de la

ciudad de Mexico. Inoculación experimental Suppl. 149

Vinson, J. W. and Fuller, H. S.:

Studies on Trench Fever. I. Propagation of Rickettsia-like Micro

organisms from a Patient's Blood Suppl. 152

Vischer, W. A.: Neuere Methoden zur Differenzierung von humanen und bovinen

Tuberkelbakterien 741

Vischer, W. A.: Vide Roth, W.

Wagner, H. J.: Vide Gillissen, G.

Watler, D. C.; Bras, G. and Brooks, S. E. H.:

The Incidence of Malignant Neoplasms in Jamaica 698

Westphal, O. und Lüderitz, O.:

Chemie bakterieller O-Antigene $\quad 870$

Weyer, F.: $\quad$ Beobachtungen an einem Stamm von «Maculatum Disease* . Suppl. 167

Wiedermann, G.: Vide Flamm, H.

Wigglesworth, J. S.: Vide Dawkins, M. J. R.

Wirka Jr., H. W.: Vide Lalich, J. J.

Witz-Berger, M. A.: Vide Lutz, A.

Yuasa, S.: $\quad$ Vide Takaki, F.

Zoixinger, H. U.: Differentialdiagnose der Schrumpfnie $\Gamma$ en 258

Zschoch, H.: Vide Mahnke, P.-F.

Gesellschaftsbekichte - Society Transactions - Sociétés

Schweizerische Mikrobiologische Gesellschaft, 20. Jahresversamm

lung, 17. und 18. Juni 1961, in Bern - Société Suisse de Microbiologie,

20e Assemblee annuelle, les 17 et 18 juin 1961, à Berne 731

Mitgliederliste der Schweizerischen Mikrobiologischen Gesellschaft -

Membres de la Société Suisse de Microbiologie 1036

Freie Vereinigung der Schweizer Pathologen. 26. Jahresversammlung

in Basel, 19. bis 20. November 1960 - Association Libre des Patholo-

gistes Suisses. 26e Assemblee annuelle à Bale, les 19 et 20 novembre

1960220

Proceedings of the Seventh International Conference of the Interna

tional Society of Geographical Pathology, London, June 28th-30th,

$1960 \quad 425$

Personalia

Prof. Dr. H. Mooser - Festschrift, zum 70. Geburtstag gewidmet,

3. Mai 1961 Supplementum

Prof. Dr. H. Mooser - Anniversary Issue, dedicated to his 70th

Birthday, May 3, $1961 \quad$ Supplementum

Prof. Dr. Hugo Braun zum 80. Geburtstag 219

Buchbesprechungen - Book Reviews - Livres Nouveaux 154, 279, 422, 730, 1042

Varia 284, 1042

Index Rerum 1135

Index Autorum 1161 